\title{
Mitral repair failures are not the robot's fault!
}

\author{
W. Randolph Chitwood, Jr, MD
}

\author{
From the Department of Cardiovascular Sciences, Brody School of Medicine, East Carolina University, Green- \\ ville, NC. \\ Disclosures: Author has nothing to disclose with regard to commercial support. \\ Received for publication Sept 2, 2017; accepted for publication Sept 2, 2017; available ahead of print Oct 3, 2017 \\ Address for reprints: W. Randolph Chitwood, Jr, MD, 146 E Longmeadow Rd, Greenville, NC 27858 (E-mail: \\ chitwoodw@ecu.edu). \\ J Thorac Cardiovasc Surg 2018;155:e17-8 \\ $0022-5223 / \$ 36.00$ \\ Copyright (c) 2017 by The American Association for Thoracic Surgery \\ https://doi.org/10.1016/j.jtcvs.2017.09.007
}

Mitral valve repairs can fail! Many of us were taught that a good repair would last a lifetime without a leak. Not true! Degenerative mitral disease is diseased tissue that is not normal. David and colleagues, master surgeons using proven repair techniques, followed repair patients using echocardiography for 20 years. In 840 patients, they reported a $5.9 \%$ failure rate with a $91 \%$ freedom from reoperation; however, only $69 \%$ were free ultimately from moderate to severe regurgitation. ${ }^{1}$ In 1218 patients, Suri and colleagues ${ }^{2}$ showed at 15 years that $13 \%$ had greater than moderate mitral regurgitation with $6.9 \%$ reoperations. These and many other published reports show us that repair failures can happen even in the best hands and with classic surgical techniques. Repair failures develop from progression of disease, endocarditis, or technical problems. Untreated primary lesions, annuloplasty prosthesis dehiscence/mismatch, leaflet suture tears, over/underresection, and excessive leaflet tethering are primary causes of technical failures. Leaflet fibrosis, chordal elongation or rupture, calcification, and tissue ingrowth can also result in a late failure.

Robotic mitral surgery evolved in a linear progression via minimally invasive approaches that have equivalent results as traditional operations. The Mayo Clinic group ${ }^{3}$ found in matched cohorts of robotic and sternotomy repair patients that outcomes were similar, despite longer perfusion and arrest times. In the current report by Taggarse and colleagues, ${ }^{4} 619$ robot-assisted mitral repair patients were followed with only $1.1 \%$ requiring a reoperation. Other large, robot-assisted procedure series have demonstrated excellent repair rates with few reoperations. Murphy and colleagues $^{5}$ reported 1257 repairs, among which $3.8 \%$ of patients required a reoperation. However, in the later half of the series, failures dropped to $0.9 \% .^{5}$ Our inaugural series of 944 patients had a $2.5 \%$ failure rate for concomitant operations and $1.7 \%$ with a lone repair. ${ }^{6}$

The importance of the article by Taggarse and colleagues ${ }^{4}$ is in the detailed description of the mechanism of failure in robot-assisted mitral repairs. Moreover, the authors suggest ways to minimize failures. All of the surgeons used the same repair technique, namely a

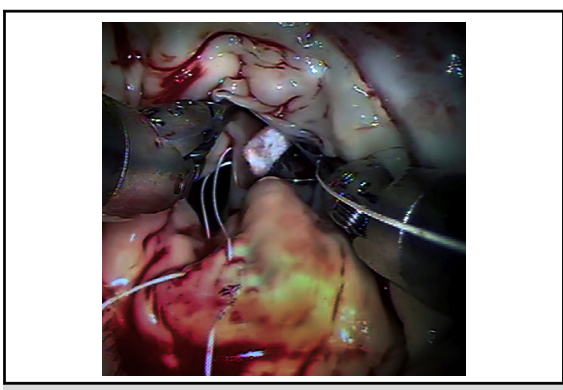

Robot-assisted mitral repair: Excellent papillary muscle access placing polytetrafluoroethylene neochords.

\section{Central Message}

Mitral valve repairs can fail! This is diseased tissue. The authors analyze the mechanism of their very few failures and continue to show that these are not related to using robot assistance.

See Article page e13.

triangular resection with or without neochords and a single length trigone to trigone annuloplasty band. Perhaps this standardized technique aided in getting such good results. Of the 5 repair failures, 4 patients had complex disease. The mechanism of failure was either an annuloplasty band dehiscence, ruptured anterior leaflet chords, elongated posterior leaflet chords, or a detached neochord. In most patients there was a mixture of reasons. The article reaffirms that both 2-dimensional and 3-dimensional transesophageal echocardiography should be in use in operating rooms to disclose complex pathology that may not be addressed otherwise. Three failures were early, suggesting technical problems that may have been avoided by fine echocardiography analysis.

I applaud the authors for carefully analyzing the reasons and possible predictors of repair failure. They dispel the notion that a robot-assisted operation, in the right surgeon's hands, can render a less-than-adequate repair. By now we should believe that failures are not the robot's fault.

\section{References}

1. David TE, Armstrong S, Mcrindle BW, Manlhiot C. Late outcomes of mitral valve repair for mitral regurgitation due to degenerative disease. Circulation. 2013;127: 1485-92.

2. Suri RM, Clavel MA, Schaff HV, Michelena HI, Huebner M, Nishamura R, et al. Effect of recurrent mitral regurgitation following degenerative mitral valve repair: long-term analysis of competing outcomes. J Am Coll Cardiol. 2016;67:488-98.

3. Suri RM, Burkhart H, Daly RC, Park SJ, Sundt TM III, Li Z, et al. Robotic mitral valve repair for all prolapse subsets using techniques identical to open valvuloplasty: establishing the benchmark against which 
percutaneous interventions should be judged. J Thorac Cardiovasc Surg. 2011;142:970-9.

4. Taggarse A, Dearani JA, Daly RC, Anwer LA, Choi W, Michelena HI, et al. Reoperation rate for recurrent mitral disease is low after robotically assisted mitral valve repair. J Thorac Cardiovasc Surg. 2018;155:e13-5.
5. Murphy DA, Moss E, Binongo J, Miller JS, Macheers SK, Sarin EL. Expanding role of endoscopic robotics in mitral valve surgery: 1,257 consecutive procedures. Ann Thorac Surg. 2015;100:1675-81.

6. Chitwood WR. Robotic mitral valve surgery: overview, methodology, results, and perspective. Ann Cardiothorac Surg. 2016;5:544-55. 